\title{
Prognostic Factors in Hemodialysis Patients: Experience of a Havana Hospital
}

\author{
Julio Valdivia MD PhD, Carlos Gutiérrez MD PhD, Janete Treto MD, Ernesto Delgado MD, Daymiris Méndez MD, \\ Irma Fernández MD, Anselmo Abdo MD PhD, Lourdes Pérez MD, Mabel Forte MD, Yanisbell Rodríguez MD
}

\begin{abstract}
INTRODUCTION Knowledge of prognostic factors in end-stage renal disease patients has improved dialysis management and methods for reducing morbidity and mortality, underlining the importance of identification, prevention and control of these factors.
\end{abstract}

OBJECTIVE Identify factors affecting prognosis (survival or death) in hemodialysis patients at the Medical-Surgical Research Center in Havana over a ten-year period.

METHODS Descriptive, prospective study of 81 end-stage renal disease patients who received hemodialysis at the Medical-Surgical Research Center from 1995 to 2004. Prognostic factors were identified at initiation of and during dialysis treatment, using chi square, $\mathrm{t}$ test, McNemar test, Kaplan Meier analysis, log-rank test and Cox regression model, with significance threshold set at $p<0.05$.

RESULTS Hypertension and diabetes were the leading causes of endstage renal disease. Six patients were referred late. Mean survival was 4.4 years; with survival of $86.6 \%, 54.7 \%$ and $26.6 \%$ at one, three and five years respectively. Factors predictive of decreased survival

\section{INTRODUCTION}

In recent decades, chronic kidney disease (CKD) has become a serious global health problem, its epidemiological picture revealing substantial and even alarming increases in both incidence and prevalence. The number of patients with end-stage renal disease (ESRD) continues to grow rapidly,[1] requiring major investment of resources in medical care. Despite better management of dialysis patients, morbidity and mortality continue to rise. Thus, identification, prevention and control of CKD risk factors before, at initiation of, and during dialysis are important for patient outcomes, population health and health systems.[2-4]

The increasing prevalence of CKD reflects the increasing prevalence of its leading causes, such as diabetes and hypertension, as well as with worldwide trends in aging. Thus, early in CKD progression, control of underlying causes is key, but in later stages, renal replacement therapies become necessary.

Cuba has a CKD prevention program that covers the whole population through family physicians and community nephrologists (integrated with secondary and tertiary care for dialysis and kidney transplant patients), which contributes to decreasing late diagnosis of this disease, a problem everywhere. Early diagnosis aids comprehensive patient care prior to dialysis and kidney transplantation and improves patient survival. $[2,5,6]$

Although specifics are not completely known for all factors predictive of hemodialysis patient survival, the influence of many of them on patient progress is known. Some, such as diabetes, are causes of ESRD; others include advanced age, late diagnosis and referral to nephrologist, malnutrition, and vascular access problems. It is important to identify these factors in order that were most frequent at initiation of hemodialysis were hypertension and chronic anemia (both present in $95.9 \%$ of cases); malnutrition, hypoalbuminemia, cardiovascular disease and chronic liver disease increased during treatment while hypertension decreased. In multivariate analysis, prognostic factors that significantly predicted decreased survival were hypertension, inadequate vascular access and diabetes. Patients aged $\geq 60$ years and those with malnutrition, hypoalbuminemia, anemia, cardiovascular disease or liver disease had lower survival figures at the end of the study period. Leading causes of death were infections $(45.2 \%)$ and cardiovascular disease $(41.9 \%)$; the latter was present in $93.5 \%$ of deaths, independent of underlying cause of death.

CONCLUSIONS Survival of hemodialysis patients diminished at five years. Some negative predictive factors are present at initiation of hemodialysis, such as diabetes, hypertension and chronic anemia; others increased later, including malnutrition, hypoalbuminemia, cardiovascular disease and liver disease.

KEYWORDS Hemodialysis, prognostic factors, survival, chronic kidney disease, end-stage renal disease, Cuba to develop comprehensive risk reduction strategies to facilitate channeling health resources and activities to their prevention and treatment.[7]

The objective of this study was to identify prognostic factors in ESRD patients on hemodialysis.

\section{METHODS}

A descriptive, longitudinal, study was done of 81 ESRD patients receiving periodic hemodialysis at the Medical-Surgical Research Center (CIMEQ, the Spanish acronym) in Havana from January 1995 through December 2004. Each admission to hemodialysis was considered one case, for a replacement therapy population of 96 , since 15 patients returned to hemodialysis after transplant failure and were considered new cases for purposes of this analysis.

Included were end stage, or stage 5, CKD patients (dialysis-dependent ESRD patients) aged $\geq 15$ years who had been in a hemodialysis program for at least three months. Excluded were patients on temporary hemodialysis or who had been receiving treatment for less than three months, those for whom hemodialysis was permanently discontinued, and patients whose treatment began with peritoneal dialysis or who were transferred to peritoneal dialysis. Patient data were recorded from initiation of hemodialysis until the end of the study, transfer to renal transplant therapy or death.

The following variables were analyzed:

- Age

- Sex

- Causes of ESRD (hypertension; diabetes; chronic glomerular diseases; polycystic kidneys; urological disorders, such as 
vesicoureteral reflux, obstructive uropathy and kidney stones; vasculitis; idiopathic causes)

- Late referral (first consult with nephrologist less than nine months before initiation of replacement therapy)[6]

- Malnutrition (body mass index, BMl $<18 \mathrm{~kg} / \mathrm{m}^{2}$ at beginning of hemodialysis and/or during last six months before end of treatment or end of study)[8]

- Hypoalbuminemia (serum albumin $<3.5 \mathrm{~g} / \mathrm{dL}$ at beginning of hemodialysis and/or during six months before end of treatment or end of study)[9]

- Uncontrolled hypertension (blood pressure $\geq 140 / 90$ at beginning of hemodialysis and/or at over $50 \%$ of monitoring checkups during hemodialysis followup)[10]

- Anemia (hemoglobin $<11 \mathrm{~g} / \mathrm{dL}$ at beginning of hemodialysis and/or at over $50 \%$ of monitoring checkups during hemodialysis followup)[11]

- Inadequate vascular access (absence of arteriovenous fistula or vascular graft, or ones that did not permit sufficient flow for hemodialysis)

- Cardiovascular disease (including left ventricular hypertrophy, angina, myocardial infarction and heart failure)

- Diabetes (according to clinical diagnosis based on fasting hyperglycemia recorded in patient histories)[12]

- Chronic liver disease (generally caused by hepatitis B or C virus)

- Inadequate diet and/or fluid intake (intake of more food and liquids than appropriate causing hydrosaline overload and electrolyte disorders requiring modification of dialysis strategy; weight gain $>6 \%$ )

- Survival

- Underlying causes of death of patients who died during study period

Analysis Information was processed using SPSS version 13.0 statistical software. Summary descriptive measures were used: mean and standard deviation for quantitative variables, and percentage for qualitative variables. The chi-square test was used for comparison of qualitative variables and t test for quantitative variable means. The McNemar test was used to compare presence of prognostic factors at initiation of and during dialysis treatment, significance level set at $p<0.05$. The Kaplan Meier method was used for survival analysis. A log-rank test was used to compare different levels of a single variable. A Cox regression model was fitted to assess risk of death for a given prognostic factor (presence or worsening during the study).

Ethics This was a noninterventional descriptive study based on analysis of hemodialysis patient records, without treatment modification. Patient identification information was kept confidential. The project was approved by CIMEQ's ethics committee and scientific advisory council.

\section{RESULTS}

Mean patient age was $40.9 \pm 12.9$ years; there were no age differences by sex. Most subjects were men (60/81, 74.1\%).

Only $6.2 \%$ of patients had late referral to a nephrologist. The leading causes of ESRD were hypertension and diabetes, in 25\% (24/96) and $21.9 \%(21 / 96)$ of cases, respectively; followed by glomerular disease $(20.8 \%, 20 / 96)$, polycystic kidney $(18.8 \%, 18 / 96)$, urological conditions $(9.4 \%, 9 / 96)$, and vasculitis $(1 \%, 1 / 96)$. Some $(3.1 \%$, $3 / 96)$ of ESRD cases were of unknown etiology.
Factors present in patients at initiation of and during dialysis treatment are listed in Table 1. Considerable uncontrolled hypertension and anemia were observed at treatment initiation. There were substantial increases in chronic liver disease, malnutrition, hypoalbuminemia and cardiovascular diseases over the course of treatment, while there was a significant decrease in uncontrolled hypertension.

Table 1: Prognostic factors in ESRD patients at initiation and during $^{\text {a }}$ hemodialysis, 1995-2004 $(n=96)$

\begin{tabular}{|l|r|r|}
\hline Factor & $\begin{array}{c}\text { At initiation } \\
\text { No. (\%) }\end{array}$ & $\begin{array}{c}\text { During dialysis } \\
\text { No. (\%) }\end{array}$ \\
\hline Late diagnosis & $6(6.3)$ & $-^{\mathrm{b}}$ \\
\hline Age $\geq 60$ years at initiation & $4(4.2)$ & $-^{\mathrm{b}}$ \\
\hline Malnutrition & $4(4.2)$ & $21(21.9)$ \\
\hline Hypoalbuminemia & $5(5.2)$ & $24(25.0)$ \\
\hline Uncontrolled hypertension & $92(95.8)$ & $68(70.8)$ \\
\hline Anemia & $92(95.8)$ & $90(93.8)$ \\
\hline Inadequate vascular access & $13(13.5)$ & $17(17.7)$ \\
\hline Cardiovascular disease & $19(19.8)$ & $74(77.1)$ \\
\hline Diabetes mellitus & $21(21.9)$ & $21(21.9)$ \\
\hline Chronic liver disease & $2(2.1)$ & $60(62.5)$ \\
\hline Inadequate diet and/or fluid intake & $-{ }^{c}$ & $33(34.4)$ \\
\hline
\end{tabular}

${ }^{a}$ At any point during survival on dialysis

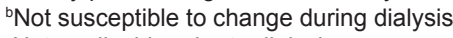

'Not applicable prior to dialysis

ESRD: end-stage renal disease

Mean hemodialysis patient survival at the end of the study period was 4.4 years, (95\% Cl: 2.2-5.3 years). At one year, survival was $88.6 \%$, falling to $54.7 \%$ at three years and $26.6 \%$ at five years (Figure 1).

Figure 1: Cumulative survival of ESRD patients on hemodialysis, 1995-2004

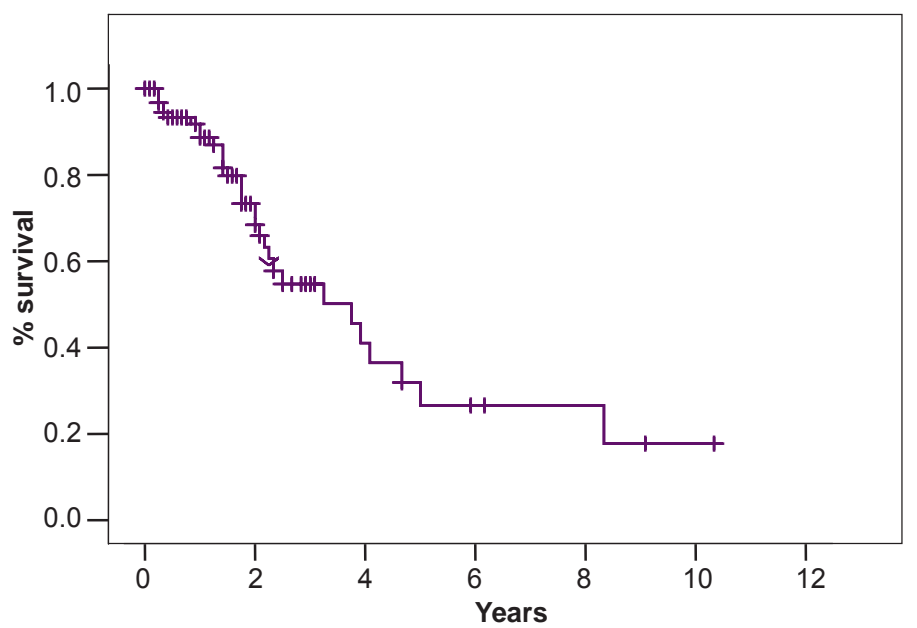

ESRD: end-stage renal disease

Prognostic factors In univariate analysis using Kaplan Meier survival curves, factors significantly increasing risk of death were hypertension $(p=0.001)$, inadequate vascular access $(p<0.001)$, diabetes $(p=0.014)$ and inadequate diet and fluid intake $(p=0.029)$. Factors predictive of death according to Cox regression analysis were uncontrolled hypertension, RR $6.57(\mathrm{Cl}$ 1.09-39.28, $p=0.039$ ), inadequate vascular access, $R R 4.66$ (Cl 1.63-13.37, $\mathrm{p}=0.004)$ and diabetes, RR $2.84(\mathrm{Cl} 1.15-7.02$, $p=0.023$ ) (Table 2). 
Table 2: Hemodialysis patient survival by prognostic factor, 1995-2004

\begin{tabular}{|c|c|c|c|c|}
\hline \multirow{2}{*}{ Factor } & \multicolumn{4}{|c|}{ Survival (\%) } \\
\hline & 1 year & 3 years & 5 years & p Value \\
\hline Age $\geq 60$ years & 100.0 & 75.0 & 0.0 & \multirow{2}{*}{0.814} \\
\hline Age $<60$ years & 91.4 & 53.5 & 28.2 & \\
\hline Malnutrition & 89.7 & 51.7 & 17.2 & \multirow{2}{*}{0.234} \\
\hline No malnutrition & 88.7 & 56.6 & 35.3 & \\
\hline Hypoalbuminemia & 87.0 & 47.0 & 22.4 & \multirow{2}{*}{0.408} \\
\hline No hypoalbuminemia & 87.8 & 62.8 & 50.3 & \\
\hline Hypertension & 83.6 & 40.0 & 15.3 & \multirow{2}{*}{0.001} \\
\hline No hypertension & 100.0 & 100.0 & 100.0 & \\
\hline Anemia & 87.4 & 48.4 & 32.6 & \multirow{2}{*}{0.441} \\
\hline No anemia & 100.0 & 75.0 & 75.0 & \\
\hline Inadequate vascular access & 70.1 & 22.7 & 0.0 & \multirow{2}{*}{$<0.001$} \\
\hline Adequate vascular access & 92.0 & 64.7 & 43.5 & \\
\hline Cardiovascular disease & 88.0 & 51.8 & 30.9 & \multirow{2}{*}{0.123} \\
\hline No cardiovascular disease & 100.0 & 50.0 & - $^{a}$ & \\
\hline Diabetes mellitus & 85.0 & 25.0 & 0.0 & \multirow{2}{*}{0.014} \\
\hline No diabetes mellitus & 93.7 & 63.3 & 33.6 & \\
\hline Liver disease & 88.4 & 48.5 & 16.2 & \multirow{2}{*}{0.728} \\
\hline No liver disease & 87.2 & 56.1 & 42.0 & \\
\hline Inadequate diet \& fluid intake & 90.0 & 44.2 & 8.8 & \multirow{2}{*}{0.029} \\
\hline Adequate diet \& fluid intake & 92.5 & 61.0 & 43.6 & \\
\hline
\end{tabular}

aby five years, all surviving patients had developed cardiovascular disease

Table 3: Underlying cause of death, associated vascular disease in ESRD patients on hemodialysis, 1995-2004 $(n=31)$

\begin{tabular}{l|r|r|}
\hline Underlying cause & $\begin{array}{c}\text { Deaths } \\
\text { No. (\%) }\end{array}$ & $\begin{array}{c}\text { Associated CVD } \\
\text { No. (\%) }\end{array}$ \\
\hline Infection & $14(45.2)$ & $12(85.7)$ \\
\hline Generalized & $5(35.7)$ & $4(80.0)$ \\
\hline Respiratory & $4(28.5)$ & $3(75.0)$ \\
\hline Endocarditis & $3(21.4)$ & $3(100.0)$ \\
\hline Acute encephalitis & $2(14.2)$ & $2(100.0)$ \\
\hline Vascular disease & $13(41.9)$ & $13(100.0)$ \\
\hline Acute myocardial infarction & $5(38.5)$ & $5(100.0)$ \\
\hline Heart failure & $1(7.7)$ & $1(100.0)$ \\
\hline Pericarditis & $2(15.4)$ & $2(100.0)$ \\
\hline Stroke & $4(30.8)$ & $4(100.0)$ \\
\hline Ruptured aneurysm & $1(7.7)$ & $1(100.0)$ \\
\hline Other & $4(12.9)$ & $4(100.0)$ \\
\hline Hepatic cirrhosis & $2(50.0)$ & $2(100.0)$ \\
\hline Cancer & $1(25.0)$ & $1(100.0)$ \\
\hline Head trauma & $1(25.0)$ & $1(100.0)$ \\
\hline Total & $31(100.0)$ & $29(93.5)$ \\
\hline
\end{tabular}

CVD: cardiovascular disease ESRD: end-stage renal disease

Underlying causes of death in hemodialysis patients were infections in $45.2 \%(14 / 31)$ and cardiovascular diseases in $41.9 \%$ $(13 / 31)$. In the latter group, acute myocardial infarction predominated $(38.5 \%, 5 / 13)$. Other causes accounted for $12.9 \%$ of deaths (cirrhosis of the liver, cancer and head trauma). Regardless of underlying cause of death, $93.5 \%$ of those who died had cardiovascular disease (Table 3).

\section{DISCUSSION}

The majority of hemodialysis patients in this study were men, congruent with studies in Europe.[13] It has been suggested that men with glomerular disease may have worse prognosis, but there is no conclusive evidence that sex is a determining factor in CKD progression.[13,14]

Hypertension, diabetes and glomerular diseases were the leading causes of CKD in these hemodialysis patients, similar to reports from other studies.[14,15] Hypertension is a cause, consequence and aggravating factor of CKD, and is highly prevalent in hemodialysis patients. Hypertension is often determined to be the cause of CKD by exclusion of other causes; defining hypertension as causal without histological confirmation of nephroangiosclerosis may lead to overestimation. This might constitute bias and be a study limitation, resulting from decisions common in medical practice to dispense with renal biopsy in these patients, since biopsy benefits may not outweigh risks.[16] Diabetic nephropathy is, along with hypertension, a major cause of CKD, consistent with our findings. An alarming global increase has been reported in incidence of diabetic nephropathy in type 2 diabetes, progressively displacing glomerular diseases among the main CKD etiologies.[16]

The late nephrology referral rate seen in our patients is a satisfactory finding when compared with reports ranging from $25 \%$ to $50 \%$.[17] One of the advantages of early diagnosis is to ensure adequate vascular access, indispensable for successful dialysis. This is consistent with our finding that the majority in this series had adequate vascular access.

In this series, $4.2 \%$ of cases were malnourished at dialysis initiation, a percentage that increased perceptibly during hemodialysis. Malnutrition can coincide with development of CKD due to the influence of underlying causes, and has been reported in $40 \%$ to $50 \%$ of patients at dialysis initiation,[18] proportions much higher than in our sample, for reasons that deserve further investigation. The causes of malnutrition are many: among them, appetite suppressants, certain socioeconomic and cultural conditions, comorbidity and depression. Hormonal imbalances associated with CKD_-peripheral insulin resistance, secondary hyperparathyroidism and low levels of growth hormone-are conducive to malnutrition.[19] It is important to clarify that BMI was used to evaluate nutritional status, as has been done by others,[20] without analyzing other aspects, such as anthropomorphic variables, biochemical imbalances, body composition and diet. Thus, this could result in underreporting of malnutrition in patients before and during dialysis, a study limitation to bear in mind for future research.

In addition to the abovementioned factors, others can lead to impaired nutrition in dialysis patients, including dialysis technique, nutrient loss during dialysis (water-soluble vitamins, amino acids and peptides) and the nausea and vomiting that frequently accompany hemodialysis. Furthermore, blood contact with the dialysis membrane triggers an inflammatory response that stimulates protein catabolism; response intensity depends on membrane composition, and is more pronounced with cellulose membranes.[21]

We found no statistically significant effect of serum albumin values on survival, possibly a result of small sample size. Serum albumin is a biochemical marker that can decrease modestly with the reduced protein and calorie intake associated with uremic syndrome, without significant comorbidity or elevated proinflammatory cytokines; this imbalance is known as type 1 malnutrition. In other cases, hypoalbuminemia can be substantial and be associated with elevated resting energy expenditure, increased oxidative stress and protein metabolism, and there can also be considerable 
comorbidity and elevated concentrations of proinflammatory cytokines; this state is known as type 2 malnutrition.[22]

Uncontrolled hypertension decreased dramatically over the course of dialysis treatment, although it continued to be a problem, as reported for other series.[22] This implies that in addition to volume overload, other mechanisms must influence pathogenesis of hypertension. The possible mechanisms implicated are related to increase in peripheral vascular resistance. It is known that worldwide some $80 \%$ to $90 \%$ of patients enter dialysis with hypertension, which does not seem to be controlled with the dialysis treatment they normally receive. In some patients, blood pressure can rise during a hemodialysis session as a paradoxical side effect of ultrafiltration, due to the renin-angiotensin-aldosterone system reaction to excessive volume loss.[23]

Anemia showed few changes over the course of treatment, maintaining a prevalence of $93.8 \%$. This may be because our patients did not receive erythropoietin systematically until the end of the study; anemia is common in ESRD patients who are not receiving erythropoietin, and our levels may have remained high because the drug was not available until the end of the study period. In dialysis patients, anemia can considerably affect various organs and systems, primarily the cardiovascular and endocrine systems and cognitive function.[24] It has been shown that for each $\mathrm{g} / \mathrm{dL}$ increase in hemoglobin, relative risk of death decreases by $5 \%$ and of hospitalization by $4 \% .[25,26]$ Despite this, we found no significant effect of anemia, and the proportion of anemic patients did not change appreciably over the study.

Inadequate vascular access for hemodialysis in this series was a prognostic factor that influenced survival. These results concur with reports from other authors, in which the greatest risk of mortality is related to more frequent infections in patients with suboptimal vascular access.[27]

The high prevalence of CVD in ESRD patients is well established, and it is the leading cause of morbidity and mortality in hemodialysis. It is reported that only $16 \%$ of patients enter hemodialysis with a normal echocardiogram, $65 \%$ have left ventricular hypertrophy, $41 \%$ have ischemic heart disease and $40 \%$ have heart failure. [28] Our study found that there was a substantial increase in CVD during dialysis therapy.

Besides the well-known traditional contributors to CVD pathogenesis, dialysis patients have additional ones, including anemia, a hyperdynamic state induced by the arteriovenous fistula, secondary hyperparathyroidism, hyperphosphatemia and malnutrition. These factors do not entirely explain increased CVD in this population; and in recent years there has been reference to new, nontraditional factors that must be involved, such as oxidative stress and systemic inflammatory response.[29]

The considerable CVD increase we observed during dialysis may be related to underreporting before dialysis initiation. Additionally, absence of symptoms revealing this disease may have impeded heart disease diagnosis in the predialysis stage. Early diagnosis of CKD could enable earlier detection of CVD.

The observed negative effect of CVD on survival grew more marked over time and was most dramatic at five years, when there were no longer any survivors without CVD. Death from a cardiovascular cause is more frequent among dialysis patients and even more so in those who are diabetic and elderly.[30]

Analysis of patient survival with diabetes as the prognostic factor showed significant differences. When diabetics begin renal replacement therapy, they present greater comorbidity, greater frequency of heart failure, peripheral vascular disease and chronic liver disease. Vascular causes of death, primarily cardiovascular causes, are also the most frequent among diabetic patients on maintenance dialysis.[31-33]

A high prevalence liver disease was observed among patients in our study, even in the context of the high rates in the dialysis population globally.[16] Our results may reflect greater use of blood transfusions prior to the time when erythropoietin became available. Notably, only $25 \%$ of our patients received erythropoietin in 2000 , increasing progressively to $100 \%$ coverage reached by the study's end. Measures to prevent transmission of hepatitis $C$ virus continue to be vitally important.

In renal replacement therapy, patient survival is undoubtedly the most important question. Dialysis technique has been shown to influence survival;[34] also important is the correct prescription and adjustment of dialysis, ensuring sessions are long enough to meet patient needs.[23] Other influential factors associated with the need for or conditions of dialysis include dialysis center experience, adherence to therapy, and comorbidities such as CVD and diabetes.[34] It has been noted that the most common causes of death are, in general, more closely related to these associated factors than to the technique itself. In fact, comorbiditiesprincipally CVD and diabetes-prior to hemodialysis initiation are a key determinant of prognosis and patient survival.[34,35] These aspects were not addressed in the present study and should be explored in future research.

Our findings that infections and CVD are the primary underlying causes of death are similar to those of other reports, in which causes of vascular origin were found in up to $50 \%$ of cases, with infections in second place (the latter the most frequent cause in patients aged 20-44 years).[36,37] Potentially fatal infections are 50 times more frequent in these patients than in the general population.[38]

\section{CONCLUSIONS}

The probable negative effect of prognostic factors, particularly CVD and infections, on morbidity and survival of ESRD patients in dialysis makes prevention, identification and control of these conditions critically important for optimal patient survival. $-1 /$ -

\section{REFERENCES}

1. National Kidney Foundation. K/DOQI clinical practice guidelines for chronic kidney disease: Evaluation, classification and stratification. Am J Kidney Dis. 2002 Feb;39(2 Suppl 1):S1-266.

2. Almaguer $M$, Herrera R, Alfonso J, Magrans $\mathrm{CH}$, Mañalich R, Martínez A. Primary health care strategies for the prevention of end- stage renal disease in Cuba. Kidney Int. 2005;6(97):S4-S10.

3. Otero A, Abelleira A, Ganoso P. Enfermedad renal crónica oculta (ERCO) y factores de riesgo vascular (FRV) asociados. Estudio epidemiológico. Nefrología. 2005;25(3):276-87. Spanish.
4. Treto J, Valdivia J, Gutiérrez C, Delgado E Méndez D. Factores de riesgo en hemodiálisis. Rev Especial Medicoquir. 2007;1(9):61. Spanish.

5. Programa de Prevención de la insuficiencia renal crónica. Havana: Ministry of Public Health (CU); 1996. Spanish. 
6. Khan SS, Xue JL, Kazmi WH, Gilbertson DT, Obrador GT, Pereira BJG, et al. Does predialysis nephrology care influence patient survival after initiation of dialysis? Kidney Int. 2005 Mar;67(3):1038-46.

7. Almaguer M. Prevención de las enfermedades renales crónicas. In: Treviño A, editor. Tratado de Nefrología. Mexico: Prado; 2003. p. 2003-27. Spanish.

8. Rocco MV, Ikizler TA. Nutrition. In: Daugirdas JT, Blake PG, Ing TS, editors. Handbook of Dialysis. 4th ed. Philadelphia: Lippincott Williams \& Wilkins; 2007. p. 462-81.

9. Menéndez J. Factores de hipoalbuminemia en pacientes en hemodiálisis y la relación con la hospitalización y la mortalidad [thesis]. [Havana]: Institute of Nephrology (CU); 2006. Spanish.

10. Stidley CA, Hunt WC, Tentori F, Schmidt D, Rohrscheib M, Paine S, et al. Changing relationship of blood pressure with mortality over time among haemodialysis patients. J Am Soc Nephrol. 2006 Feb;17(2):513-20.

11. Rodríguez P, Pérez R, López JM. Anemia y su tratamiento en hemodiálisis. In: Jofré R, editor. Tratado de Hemodiálisis. 2nd ed. Barcelona: JIMS Editorial Médica; 2006. p. 581-94. Spanish.

12. Martínez-Castelao A, Hernández MD, Pascual J, Morales JM, Marcen R, Errasti P, et al. Detection and treatment of post kidney transplant hyperglycemia: a Spanish multicenter cross-sectional study. Transplant Proc. 2005 Nov;37(9):3813-6.

13. Hecking E, Bragg-Greshan JL, Rayner HC, Pisoni RL, Andreucci VE, Combe $\mathrm{C}$, et al. Haemodialysis prescription, adherence and nutritional indicators in five European Countries: results from the Dialysis Outcome and Practice Patterns Study (POPPS). Nephrology Dial Transplant. 2004 Jan;19(1):100-7.

14. Kjellstrand CM, Blagg CR, Twardowski ZJ, Bower J. Blood access and hemodialysis: Clinical experience and review of literature. ASAIO J. 2003 Nov-Dec;49(6):645-9.

15. Patel SS, Kimmel PL, Singh A. New Clinical Practice guidelines for chronic kidney disease a framework for K/DOQI. Semin Nephrol. 2002 Nov;22(6):449-58.

16. Burkart JM. Insuficiencia renal en fase terminal y diálisis. NephSAP. 2005;1:7-55. Spanish.

17. Gallego E, López A, Lorenzo I, López E, Llamas $\mathrm{F}$, Illescas ML, et al. Referencia precoz y tardía al nefrólogo, su influencia en la morbi-mortalidad en hemodiálisis. Nefrología. 2003;23(3):234-42. Spanish.

18. Pifer TB, McCullough KP, Port FK, Goodkin DA, Maroni BJ, Held PJ, et al. Mortality risk in haemodialysis patients and changes in nutritional indicators: DOPPS. Kidney Int. 2002 Dec;62(6):2238-45.

19. Marcén R. Manifestaciones clínicas y bioquímicas de la insuficiencia renal crónica. In: Hernando Avendaño L, editor. Nefrología Clínica. 2nd ed. Madrid: Panamericana; 2003. p. 707-52. Spanish.

20. Berdasco A. Evaluación del estado nutricional del adulto mediante la antropometría. Rev Cubana Aliment Nutr. 2002;16(2):146-52. Spanish.

21. Carrera Roxana B, Mengarelli MC, Najun-Zaragoza CJ. El sore de desnutricion e inflamación como predictor de mortalidad en pacientes de hemodiálisis. Dial Traspl. 2008(2):55-61. Spanish.

22. Bossola M, La Torre G, Giungi S, Tazza L, Vulpio C, Luciani G. Serum albumin, body weight and inflammatory parameters in chronic hemodialysis patients: a three-year longitudinal study. Am J Nephrol. 2008;28(3):405-12.

23. Fernández M, Teruel JL, Quereda C, Orte LM, Marcén R, Ortuño J. Hipertensión arterial prediálisis: factor de riesgo de mortalidad cardiovascular durante el tratamiento con hemodiálisis Nefrología. 2005;25 Suppl 4:S23-7. Spanish.

24. Pisoni R, Bragg-Gresham JL, Young EW, Akizawa T, Asano Y, Locatelli F, et al. Anaemia management and outcomes in 12 countries in dialysis outcomes and practice patterns study (DOPPS). Am J Kidney Dis. 2004 Jul;44(1):94-111.

25. Marín R, Goicochea MA, Gorostidi M, Cases A, Díez J, Escolar G, et al. Guía de la sociedad española de nefrología sobre riñón y enfermedades cardiovasculares. Nefrología. 2006;26(1):33-44. Spanish.

26. Leanza H, Giacoletto S, Najún C, Barreneche N. Niveles de hemoglobina y probabilidad de mejor calidad de vida en hemodializados crónicos. Nefrología 2000;20(5):442-4. Spanish.

27. Malek T, Alvarez Ude F, Gil MT, Moledous A, López-Collado M, Núñez C, et al. Cambios en el acceso vascular en una unidad de hemodiálisis ¿problemas de planificación, cambio de preferencia o cambio demográfico?. Nefrología. 2008;28(5):531-8. Spanish.

28. Wali RK, Wang GS, Gottlieb SS, Bellumkonda L, Hansalia R, Ramos E, et al. Effect of kidney transplantation on left ventricular systolic dysfunction and congestive heart failure in patients with end-stage renal disease. J Am Coll Cardiol. 2005 Apr;45(7):1051-60.

29. Cases A. Otros factores de riesgo cardiovascular y renal: Hipertrofia del ventrículo izquierdo: Fibrilación auricular: Tabaquismo: Obesidad: Factores emergentes de riesgo cardiovascular: Homocisteina: Proteina C reactiva: Fibrinógeno. Nefrología. 2004;24 Suppl(6):62-72. Spanish.

30. Collado SN, Coll E, Deleufeu R, Guerrero L, Pons M, Cruzado JM, et al. Prevalencia de enfermedad cardiovascular en la uremia y prevalencia de los factores de riesgo cardiovasculares. Nefrología. 2010;30(3):342-8. Spanish.

31. Álvaro F, Jiménez C, García F. Tratamiento de la insuficiencia renal en los diabéticos. In: Hernando Avendaño L, editor. Nefrología Clínica. 2nd ed. Madrid: Panamericana; 2003. p. 367-75. Spanish.

32. Sarnak MJ. Cardiovascular complications in chronic kidney disease. Am J Kidney Dis. 2003 Jun;41(5 Suppl):S11-7.

33. Hernández G, Rodríguez A. Resultados a corto y a largo plazo. Factores pronósticos. In: Jofre R, López Gómez JM, Luño J, editors. Tratado de Hemodiálisis. 2nd ed. Barcelona: JIMS Editorial Médica; 2006. p. 417-22. Spanish.

34. Remón C, Quirós PL, Portolés J, Marrón B. Análisis crítico de los estudios de supervivencia en diálisis. Nefrología. 2010;1(Suppl Ext 1):8-14. Spanish.

35. van Manen JG, van Dijk PC, Stel VS, Dekker $\mathrm{FW}$, Clèries $\mathrm{M}$, Conte $\mathrm{F}$, et al. Confounding effect of comorbidity in survival studies in patients on renal replacement therapy. Nephro Dial Transplant. 2007 Jan;22(1):187-95.

36. Registro Español de Enfermos Renales. Informe 2006 de diálisis y trasplante renal en España Registro Español de Enfermos Renales. Nefrología. 2009;29(6):525-33. Spanish.

37. McDonald SP, Russ GR, Kerr PG, Collins JF; Australia and New Zealand Dialysis and Transplant Registry. ESRD in Australia and New Zealand at the end of the millennium: a report from the ANCDATA registry. Am J Kidney Dis 2002 Dec;40(6):1122-31.

38. López K, Saracho R, García F, Gentil MA, Castro P, Castilla J, et al. Informe de diálisis y trasplante año 2001 de la Sociedad Española de Nefrología y Registros Autonómicos. Nefrología. 2004;24(1):21-63. Spanish.

\section{THE AUTHORS}

Julio Valdivia Arencibia (Corresponding author: jvarencibia@infomed.sld.cu), Nephrologist with a doctorate in medical sciences. Full professor and senior researcher, Medical-Surgical Research Center (CIMEQ), Havana, Cuba.

Carlos Gutiérrez Gutiérrez, nephrologist with a doctorate in medical sciences. Full professor and senior researcher, CIMEQ, Havana, Cuba.

Janete Treto Ramírez, nephrologist and family physician, CIMEQ, Havana, Cuba.

Ernesto Delgado Almora, nephrologist. Instructor at CIMEQ, Havana, Cuba.

Daymiris Méndez Felipe, nephrologist and family physician, CIMEQ, Havana, Cuba.

Irma Fernández Madero, physician specializing in biostatistics, CIMEQ, Havana, Cuba.

Anselmo Abdo Cuza, intensivist with a doctorate in medical sciences. Full professor, CIMEQ, Havana, Cuba.

Lourdes Pérez Clemente, nephrologist. Associate professor and researcher, Central Havana Pediatric Teaching Hospital, Cuba.

Mabel Forte Riverón, family physician, CIMEQ, Havana, Cuba.

Yanisbell Rodríguez Muñoz, family physician, CIMEQ, Havana, Cuba.

Submitted: November 23, 2012

Approved for publication: June 30, 2013

Disclosures: None 